\title{
SECONDARY SOMATIC NOMINATIONS IN MEDIA TEXTS COVERING ECONOMY, BUSINESS AND POLITICS SPHERES
}

\author{
Viktoriya V. Zhura \\ Volgograd State Medical University, Volgograd, Russia \\ Yuliya V. Rudova \\ Volgograd State Medical University, Volgograd, Russia \\ Yelena G. Semenova \\ Volgograd State Medical University, Volgograd, Russia
}

\begin{abstract}
The article set out to reveal the specific features of secondary somatic nominations in media texts in the spheres of economy, business, and politics. The significance of the problem under study is implied by a need for elucidating the evolution of language consciousness by shedding light on how corporeal lexis in the Russian language is involved in verbalization of reality in the spheres in question. The study demonstrated that secondary somatic nominations evolve due to transformation of the meaning of a linguistic unit, whose primary meaning is associated with various aspects of the human body existence. This transformation of the meaning seems to be a common way of denotating reality in the texts under investigation. We specified the sources of somatic expansion, whose semantic content is most frequently redefined in the thematic fields in question. We also identified the denotation areas (conceptual fields) where corporeal lexis is used in their secondary meanings. Our research demonstrated considerable pragmatic potential of the texts including somatic linguistic units. We established that their evaluative content results from axiological connotations associated with various corporeal concepts in the Russian linguoculture. Their expressiveness is achieved due to imagery created by unusual contextualization of somatic linguistic units. The results of the current study made it possible to establish the ways of transforming the meanings of somatic linguistic units in the investigated spheres in the Russian language. Transformation of the meanings of somatic lexis occurs by using metaphors, metonymy, similes, irony, epithets, oxymoron, gradation, language game, etc.
\end{abstract} axiology.

Key words: media text, economy, business, politics, somatic linguistic unit, somatic lexis, secondary meaning,

Citation. Zhura V.V., Rudova Yu.V., Semenova Ye.G. Secondary Somatic Nominations in Media Texts Covering Economy, Business and Politics Spheres. Vestnik Volgogradskogo gosudarstvennogo universiteta. Seriya 2. Yazykoznanie [Science Journal of Volgograd State University. Linguistics], 2021, vol. 20, no. 5, pp. 153-166. (in Russian). DOI: https://doi.org/10.15688/jvolsu2.2021.5.12

\section{ВТОРИЧНЫЕ СОМАТИЧЕСКИЕ НОМИНАЦИИ В МЕДИАТЕКСТАХ ЭКОНОМИЧЕСКОЙ, ДЕЛОВОЙ И ПОЛИТИЧЕСКОЙ НАПРАВЛЕННОСТИ}

\section{Виктория Валентиновна Жура}

Волгоградский государственный медицинский университет, г. Волгоград, Россия

\section{Юлия Владимировна Рудова}

Волгоградский государственный медицинский университет, г. Волгоград, Россия 


\section{Елена Геннадиевна Семенова}

Волгоградский государственный медицинский университет, г. Волгоград, Россия

Аннотация. Целью исследования стало изучение особенностей формирования вторичных номинаций на основе соматической лексики в медиатекстах экономической, деловой и политической направленности. Актуальность работы заключается в необходимости описания эволюции языкового сознания путем установления того, каким образом соматизмы русского языка участвуют в вербальном отражении действительности. Показано, что образование вторичных соматических номинаций происходит в результате переосмысления плана содержания языковой единицы, первичное значение которой связано с обозначением различных аспектов функционирования организма человека. Подобные смысловые изменения выступают распространенным способом отображения действительности в текстах указанной тематики. Детализированы источники соматической экспансии, план содержания которых наиболее часто подвергается трансформации в рассматриваемых тематических сферах. Установлены денотативные зоны (понятийные области), в рамках которых они используются во вторичных значениях. Описан прагматический потенциал высказываний, включающих соматические номинации. Их оценочная составляющая формируется на основе аксиологических смыслов, закрепленных в российской лингвокультуре за различными понятиями, ассоциируемыми с человеческим телом. Экспрессивность достигается за счет образности, создаваемой употреблением соматизмов в непривычных для адресата контекстах. Выявлены приемы создания вторичных соматических номинаций, применяемые в изучаемых текстах: метафора, метонимия, сравнение, ирония, употребление единицы в функции эпитета, оксюморон, градация, языковая игра. В.В. Журой разработаны концептуальные аспекты анализа, установлены прагматические особенности высказываний, включающих соматические номинации, и определены способы создания вторичных соматических номинаций. Е.Г. Семеновой проведен сбор и первичный анализ фактического материала. Ю.В. Рудовой осуществлен критический анализ существующих исследований по изучаемой проблематике, рассмотрены источники соматической экспансии, план содержания которых наиболее часто подвергается трансформации.

Ключевые слова: медиатекст, экономика, бизнес, политика, соматизм, соматическая лексика, вторичная номинация, оценочность.

Цитирование. Жура В. В., Рудова Ю. В., Семенова Е. Г. Вторичные соматические номинации в медиатекстах экономической, деловой и политической направленности // Вестник Волгоградского государственного университета. Серия 2, Языкознание. - 2021. - Т. 20, № 5. - С. 153-166. - DOI: https://doi.org/10.15688/ jvolsu2.2021.5.12

\section{Введение}

Стремительный прогресс медицины в XX и XXI в. привел к ее экспансии в различные сферы социальной практики человека и, как следствие, к переосмыслению роли телесного аспекта человеческого бытия. Этот процесс получил название «медикализация» [Жура, Рудова, 2014]. В социологии его обозначают как эволюцию медицины в «социетальность» [Дмитриева, 2003]. Последствия возрастающего влияния данной науки на современное общество различны и касаются как изменения моделей социального поведения и практик человека, так и их осмысления и объективации средствами естественных языков. В связи с этим актуальным становится обнаружение способов концептуализации физического бытия человека во всем его многообразии и их проявления в речемыслительной деятельности. Решение данной задачи позволит определить основные направления эволюции языкового сознания в современном российском обществе, ведущие к изменению отраженной в нем картины мира.

Подобный подход уже был реализован в ряде исследований (см., например: [Бурганова, Савельева, 2009; Голубых, 2019; Рудова, Жура, 2017; Zhura et al., 2017]). Однако объектом изучения в них выступала преимущественно рекламная коммуникация, а проникновение телесно-ориентированного сознания в другие сферы общения не получило всестороннего освещения. Одной из наиболее значимых работ, в которой были затронуты проблемы употребления соматизмов в газетных текстах, стала монография А.П. Чудинова, посвященная когнитивному исследованию политической метафоры. Автором выделены основные понятийные сферы-источники метафорической номинации - человек, социум, природа и вещи [Чудинов, 2001, с. 59-94]. Особый инте- 
рес для нашего исследования представляет субсфера «Человек», в рамках которой функционируют физиологическая, морбиальная, сексуальная метафора и метафора родства. В связи с изучением процесса создания вторичных номинаций на основе соматизмов в фокусе внимания А.П. Чудинова были физиологическая и морбиальная метафоры. Первый тип связан с переосмыслением значений названий различных органов и частей тела человека, а также их физиологических функций, во втором осуществляется смысловая перефокусировка различных семантем, сгруппированных в рамках понятийного поля патологическое состояние человеческого организ$м a$, а именно «пациенты и медицинский персонал», «диагноз», «причины и возбудители болезней», «симптомы заболеваний», «способы лечения, используемые инструменты и лекарства», «состояние пациента» [Чудинов, 2001, c. 68-77]. Объединение этих денотативных областей в пределах указанного поля основано на причинно-следственных связях, существующих между ними в объективной действительности. Отметим, что морбиальная метафора в газетном тексте рассмотрена С.В. Ляпун, однако автором не проводилось детального изучения данного стилистического явления (см.: [Ляпун, 2008]).

Поставив перед собой цель охарактеризовать возможности соматических лексем в формировании вторичных номинаций для обозначения различных аспектов деловой активности, экономической и политической деятельности, мы рассматривали оба вида метафоры (физиологическую и морбиальную), так как они охватывают все виды переосмысления, объектом которых является тело человека (от греч. soma, atos - тело).

\section{Методы и методология исследования}

В качестве источника материала мы использовали публикации, размещенные в глобальной сети Интернет в рубриках «Бизнес», «Экономика» и «Политика» ${ }^{1}$. Тексты, публикуемые в данных разделах, нами обозначены как тексты деловой, экономической и политической направленности. В связи с тем, что в ряде газет разделы «Экономика» и «Бизнес» не дифференцированы (либо статьи по бизнесу размещены в разделе «Экономика», либо подраздел «Бизнес» включен в раздел «Экономика»), мы объединили такие публикации под общим названием «тексты в сфеpax бизнеса и экономики».

Примеры вторичных номинаций (146 единиц) отбирались методом сплошной выборки. В ходе работы мы рассмотрели 200 статей, относящихся к сфере бизнеса и экономики, опубликованных в ряде интернет-изданий (СБЕР Про, Газета.ru, Известия, НВ, Мир новостей, Konkurent.ru и др.). Наряду с этим было отобрано 200 статей из рубрики «Политика» (Газета.ru, MKRU, RT, РИА Новости, Политэксперт, Новая газета, ИА «НТА Приволжье», НВ, Эхо Москвы, «Открытая» газета, Красная весна и др.). Временной период, в который были опубликованы эти материалы, составлял последние 15 лет (с 2006 по 2020 г.).

При проведении данного исследования мы опирались на ряд результатов, полученных А.П. Чудиновым, в частности его классификацию метафор, а также выделенные функции политической метафоры (номинативную, коммуникативную, прагматическую, изобразительную, инструментальную, гипотетическую, моделирующую, эвфемистическую и популяторизаторскую) [Чудинов, 2001, с. 49-51].

Под вторичной соматической номинацией в данной работе мы понимаем языковую единицу, первичное значение которой связано с различными аспектами существования организма / тела человека и подвергается переосмыслению для характеристики субъектов, их действий и взаимоотношений, объектов бизнеса, экономической и политической деятельности.

При определении диапазона исследуемых в работе вторичных номинаций мы опирались на расширенную классификацию соматизмов, включающую не только названия различных частей человеческого тела: сононимы (названия частей тела человека), остеонимы (номинаций костей и их сочленений), сплахнонимы (наименования внутренних органов), ангионимы (обозначения составных элементов кровеносной системы), сенсонимы (термины, именующие органы чувств человека), но и единицы, обозначающие различные патологии (о классификации см.: [Голодов, 2010; Лаврищева, 2018; Масалева, 2009а; 


\section{МАТЕРИАЛЫ И СООБЩЕНИЯ}

2009б; Мугу, 2003; Новрузова, 2009]). Такие лексемы квалифицированы нами как собственно соматизмы. Результаты анализа речевого материала позволили расширить классификацию на основе добавления лексем, отражающих новые денотативные зоны (или понятийные области). В связи с существованием тесных причинно-следственных связей между понятиями, обозначаемыми собственно соматизмами, и сигнификатами ряда других лексем, включающими такие признаки, как изменение состояния / статуса тела человека, соматические проявления и функции, манипуляции или воздействие на организм человека, такие лексические единицы были включены нами в «соматические номинации». Их значения, в отличие от значений собственно соматизмов, денотат которых - части организма человека, включают лишь отдельные телесно-ассоциированные семантические / сигнификативные признаки. Эти слова определены нами как условные соматизмы и также рассмотрены в работе наряду с собственно соматизмами.

В исследовании применялись процедуры семантического, концептуального, количественного и интерпретативного анализа.

\section{Результаты и обсуждение}

Количественный анализ текстов показал, что вторичные соматические номинации использованы в 40 \% публикаций на темы экономики и бизнеса и $33 \%$ - на темы политики.

Проведенная количественная оценка отобранного материала свидетельствует о распространенности рассматриваемого феномена в медиатекстах экономической, деловой и политической направленности. С одной стороны, данный факт обусловлен медикализацией общества в результате разработки и внедрения новых здоровьесберегающих технологий, появления инновационных средств и способов лечения. Медицина становится неотъемлемой частью жизни практически каждого человека, а понятия, связанные с функционированием его организма, - боль, страдание, ухудшение / улучшение физического и психического здоровья, смерть, качество жизни, - превращаются в важные экзистенциональные измерения его бытия. Особую значимость приобретает биомедицинский ракурс осмысления действительности сегодня, в эпоху пандемии и актуализации глобальных усилий по защите здоровья и жизни. С другой стороны, значительная доля явлений вторичной соматической номинации в медиатекстах экономической, деловой и политической направленности связана с особенностями их плана содержания, включающего, как показывают исследования, несколько пластов информации - о том, что сообщается, а также о позиции автора по отношению к сообщаемому (см., например: [Ляпун, 2008, с. 142; Покровская, 2006]). Модусные смыслы переносятся на второй план или в подтекст, что обусловлено своеобразным кодом политкорректности: журналист избегает прямо выражать свое отношение к тому, о чем повествует, поэтому завуалированная оценка при помощи метафорических выражений, связанных с телом человека, имеет мейотическое назначение. В этом мы видим проявление эвфемистической функции политической метафоры (по Чудинову). В то же время повышение экспрессивности высказывания, связанное с переосмыслением соматических терминов, способствует усилению его перлокутивного эффекта, что является важной целью массмедиа-коммуникации.

Корпореальность (телесность) представляет для человека ту реальность, которая неотделима от его сущности. Благодаря ее категориям человек идентифицирует и познает не только свое телесное, но и духовное начало. Закономерности существования объектов неживой окружающей действительности также зачастую осмысляются по аналогии с человеческим организмом. В связи с этим вторичные соматические номинации приобретают особые функции в текстах экономической, деловой и политической направленности: они представляют внешний и внутренний миры человека в терминах соматических понятий, что позволяет осмыслить сложные и абстрактные категории при помощи конкретно-референтных значений, то есть они выполняют инструментальную, моделирующую, а в ряде случаев и популяризаторскую функции.

В массмедийных текстах, опубликованных в рубриках «Бизнес» и «Экономика», вторичные номинации, выражающие телесно- 
ассоциированные смыслы, использованы для обозначения субъекта деятельности. В приведенных ниже примерах посредством вторичных номинаций характеризуется и оценивается его:

- экономическое положение:

И еще у нас много идей о том, как нашим пиццериям выживать в этот кризис (СБЕРПро. 08.04.2020);

Без кроссовера Datsun скорее всего не выживет, но вряд ли сейчас Nissan будет вкладывать в него деньги» (Известия. 16.05.2020);

Малый бизнес вымирает (МН. 13.11.2019);

- духовно-нравственная позиция:

Интересно, что месяцем ранее благотворительный фонд, в попечительский совет которого входит Ставницер, подставил плечо Зеленскому в борьбе с коронавирусом (НВ. 17.05.2020);

Или в воспаленных умах бухгалтеров из Минфина окончательно возобладал принцип «доить до последнего тех, кого еще можно доить»? (МH. 20.03.2020);

- социальный / профессиональный статус:

Лучшими глазами и ушами внутри компании будет ваш chattered accountant - местный сотрудник, который станет готовить все отчеты в контролирующие органы Индии (СБЕР Про. 15.05.2020);

- деятельность:

С чего бы это власть столь откровенно задирает поборы с предпринимателей, зарабатывающих на жизнь своими руками и умом, не пользующихся (в отличие от приближенных к этой власти) льготами и преференциями государства?! (МН. 20.03.2020);

- физический / биологический статус:

Коллекторы могут исчезнуть как вид (МН. 04.09.2019).

Вторичные номинации называют объект деловой активности, раскрывают его в различных экзистенциональных аспектах. При этом наиболее распространенной является оценка экономического положения:

Без масштабной инъекции ликвидности, вероятно, последовала бы череда банкротств и масштабные потери организационного капитала» (R. 11.06.2020);

На кредитной игле (МН. 05.07.2019); а также психоэмоционального статуса и духовно-нравственной позиции:

На самом деле подобная категория клиентов может создать головную боль практически любой компании (СБЕР Про. 02.04.2020);

Но зато люди с повышенной тревожностью, коих у нас в стране большинство, сохранят свои нервы (MH. 18.12.2018).

Оценочная характеристика посредством соматической лексики дается действиям и поведению субъектов и объектов экономической деятельности:

В Госдуме назвали «безумием» санкции Украины против научных учреждений РФ (Газета. 15.05.2020);

В последнее время «МН» не раз рассказывал о все более частных потугах банкиров и чиновников обложить своим пристальным внимание и «заботой» кошельки граждан России» (МН. 05.12.2019);

Полгода водили за нос, после чего согласились-таки выдать ему эту сумму... (МН. 09.03.2019).

С использованием переосмысленной соматической лексики характеризуется состояние экономической деятельности / деловой активности. При этом оценка состояния может осуществляться как эксплицитно:

Инфраструктура дышит на ладан (МH. 23.09.2019);

Именно в те годы формировался тот системный кризис, который нынче стал хроническим и трудноизлечимым (МН. 26.07.2018);

так и имплицитно:

Это якобы должно оживить российскую экономику» (МН. 07.10.2019).

Кроме того, дается характеристика способов осуществления деловой активности и факторов, влияющих на данный процесс:

Спекулятивный рост цен и паника быстро съедают сбережения (МН. 30.03.2020);

Банки по определению существуют в токсичной среде (МН. 08.11.2019);

Якобы непогашенные задолженности надуваются в пузырь, который в конце концов может лопнуть, окончательно похоронив и без того больную российскую экономику (МН.13.09.2019). 


\section{МАТЕРИАЛЫ И СООБЩЕНИЯ}

В медиатекстах, опубликованных в рубрике «Политика», соматизмы приобретают новые смыслы при описании субъекта политической деятельности. При этом часто дается характеристика его политической позиции:

По его мнению, Зеленский является «марионеткой» в руках тех, кто «находится за его спиной» (Газета. 17.05.2020);

По одной из версий, пристальное внимание к Габышеву проистекает из особенностей сознания нынешнего российского истеблишмента. Последний, мол, и сам неровно дышит к эзотерике, поэтому угрозы со стороны шамана воспринимает абсолютно всерьез (МК. 15.05.2020).

Распространенным является употребление соматической лексики для указания на недееспособность политических субъектов:

Похоже, на фоне стресса у губернатора произошло своего рода раздвоение сознания (МК. 01.05.2020);

«По странному стечению обстоятельств, МИД является всегда у нас абсолютным рассадником, как бы это сказать, шизофрении», сказал депутат в эфире телеканала «112 Украина» (МК. 12.05.2020);

Чиновник такого уровня, глава НАТО делает такие дерзкие, громкие заявления, которые граничат с потерей дипломатических отношений между странами, не подтверждая это ничем, не давая никаких ссылок, никакой фактуры. Это уже их безумие в агонии, которую они сегодня переживают» (MK. 15.05.2020).

Для выражения подобных смыслов в высказывании, как правило, актуализируются соматические признаки, указывающие на психоментальные расстройства человеческого организма.

Вторичные соматические номинации используются при определении духовнонравственной позиции субъекта политической деятельности:

Россия протянула руку помощи Европе в борьбе с невидимым противником - коронавирусом (МК. 12.05.2020);

Отдавших жизнь за то, чтобы сей господин мог родиться на свет, кушать яблоки и, повзрослев, походя плюнуть на подвиг ни много ни мало 27 миллионов советских людей, погибших в той войне (МК. 11.05.2020);
Возглавить комиссию должен моральный авторитет... Он будет беспощадным диагностом с приобретенным за восемь лет иммунитетом. Заразить его тяжело (РР. 01.03.2012);

Те единичные сотрудники оттуда, которые никогда не слышали о взятках, послужат прототипом для создания вакцины (РР. 01.03.2012).

Выражение путем переосмысления плана содержания соматической лексики получает политическая ситуация:

В НАТО после пандемии начался новый виток русофобной истерики (МК. 12.05.2020);

Наконец-то, мол, регионы вдохнули полной грудыю прописанной в Конституции свободы (МК. 14.05.2020);

Как хочется, чтобы общая коронавирусная беда прочистила отравленные фейками мозги... (MK. 16.05.2020);

Проблема носит фундаментальный и системообразующий характер. Это настоящая пандемия, поразившая страну. Ее опасность в том, что она имеет латентный характер, ее невозможно выявить и диагностировать ровно до того момента, пока очередной сотрудник правоохранительных органов не будет арестован при получении взятки. Очередность арестов - это недоразумение и признак гниения (РР. 01.03.2012).

Употребление соматизмов является также распространенным способом оценки политических действий:

Россия никому не угрожает, а ударный кулак у российской границы собирает именно НАТО (РБК. 07.03.2020);

«Относиться серьезно к бульканью из его рта невозможно по определению», сказал Соловьев (МК. 11.05.2020);

При этом нынешний президент Украины до сих пор не понимает свою ответственность перед украинцами, пытаясь «морочить им голову», рассказывая «сказки» по заученным текстам (ПЭ. 28.04.2020).

Приведенные выше примеры из публикаций на темы экономики, бизнеса и политики обнаруживают особенности семантических трансформаций, происходящих при формировании вторичной соматической номинации.

Первоначально, выходя за рамки медицинского дискурса, значение соматизма эволюционирует в направлении от конкретно- 
смыслового (конкретно-референтого) наполнения в сторону размывания его семантических границ. Таким образом, лексическая единица приобретает диффузное значение. Рассмотрим в качестве примера слово боль. Семантический анализ контекстов его употребления в изучаемых текстах (головная боль крымских депутатов; с ее помощью можно выявить «боль» потребителя; фантомные боли рубля; Госдеп пообешал России «последствия и боль» за украинских моряков и др.) показал, что инвариантом его значения можно считать «отрицательное явление / переживание».

Далее происходит конкретизация диффузного значения соматизма. Она осуществляется на основе взаимодействия его семантики с семантикой ближайшего лексического контекста, определяемого рамками денотативной зоны, в которой создается вторичная номинация.

Например:

По словам члена Совета Федерации Владимира Джабарова, принятая польскими властями новая стратегия национальной безопасности говорит о том, что страна испытывает ностальгическую боль из-за России (МК. 13.05.2020).

Переосмысление значения выражения исnытыввать боль связано с формированием новых семантических актантов / валентностей глагола испытывать (страна вместо живое существо, ностальгическая вместо сильная / пульсирующая, из-за России вместо из-за травмы), актуализация которых определяется характером денотативной зоны. Таким образом, в данном контексте у соматизма боль формируется вторичное значение: «испытывать неприятное эмоциональное переживание, связанное с тоской по временам, когда эта страна (Польша) была союзником России», которое имеет абстрактно-референтный характер.

Трансформация значения при образовании вторичной номинации на основе соматизма может быть представлена схематично (см. рисунок).

Образование вторичных номинаций в медиатекстах экономической, деловой и политической направленности происходит с применением разных приемов. Ведущими являются:

- сравнение:

Власти только бессвязно разевают рты, как аквариумные рыбки (МН. 30.03.2020);

Саратовские чиновники вруг, как дышат (ПВ. 21.10.2019);

Эта экономическая политика РФ выглядит примерно, как человек, болеющий от голода, но сидящий на бочке золота (МН. 23.09.2019);

- метафора:

Режим самосохранения для руководителя это смерть (СБЕР Про. 13.05.2020);

гангрена армии (КП. 28.01.2006);

атрофия стыда и морали (ОГ. № 38(530) от 03.10.2012);

- метонимия:

с появлением все большего числа независимых от Запада экономических держав, способных платить своим мозгам и рукам без посредников (P. 31.03.2020);

- употребление языковой единицы в функции эпитета:

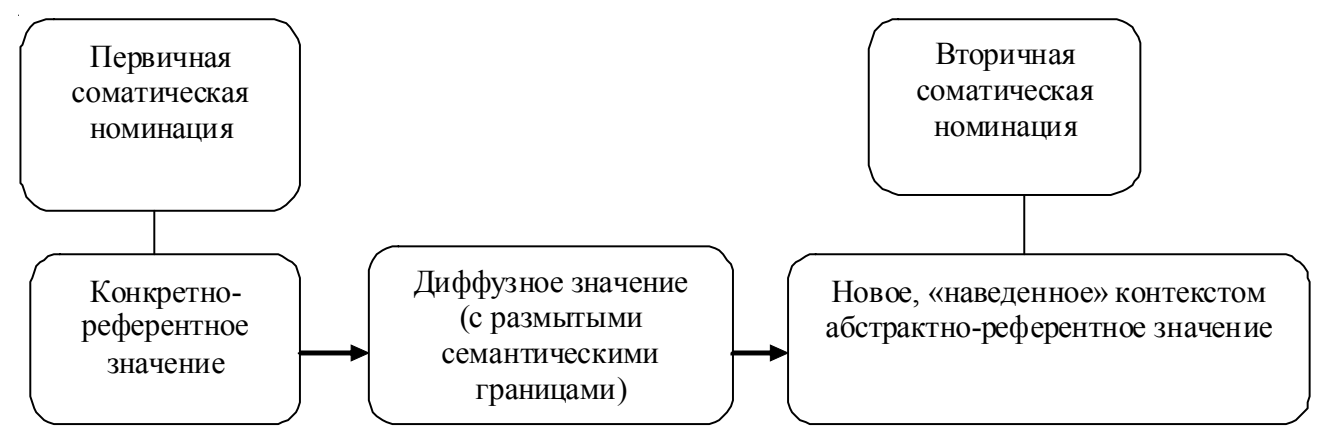

Трансформация значения вторичной соматической номинации

Transformation of secondary somatic meaning 
самоубийственными экономическими санкциями; кровно заработанные деньги; атипичное здравоохранение (НГ. 19.06.2006);

- а также использование устойчивых фразеологических сочетаний, содержащих соматизмы с экспрессивно-оценочными коннотациями:

Опасно безрассудно забегать вперед, но нельзя и сидеть сложа руки, избегая ответственности(МК. 11.05.2020);

Стало понятно, что надо от них уходить, так как они нас держат за горло и не дают проекту развиваться (МК. 13.05.2020).

В случае метафорического и метонимического переноса при формировании нового значения реализуется несколько возможностей переосмысления языковых единиц, ассоциированных с телесностью:

- переосмысление физиологических процессов, протекающих в организме человека:

Структура госуправления осталась без изменения еще с советских времен, несмотря на все реформаторские потуги (Коммерсант. 14.05.2014);

Финансовые планы кировских чиновников дышат осторожным оптимизмом (ФП. 16.09.2009);

И, следовательно, «брать» избирателя нужно, пока он «тепленький» (МК. 16.05.2020);

- смысловая переоценка патологических состояний человеческого организма:

Синдром приобретенной дезинформации (Коммерсант. 13.06.2020);

...в России наблюдается «пугающий» уровень «атрофии» общественной активности (ИА. 09.10.2006);

Это, по его мнению, может привести к отторжению некоторых территорий Украины (МК. 16.05.2020);

Почему все чиновники Минздрава близорукие (НГ. 16.10.2006);

Мы же и насытим его наиболее явными симптомами болезни. Не ограничиваясь, такими как: 1) невыносимая тяга к дорогим иномаркам; 2) болезненное стремление отдельных сотрудников завести себе личного портного, с целью пошива модной формы (РР. 01.03.2012);

Закупорка реальных каналов коммуникации общества и власти (НезГ. 04.04.2017);

- переосмысление функционала медицинских вмешательств и средств воздействия на человеческий организм:
На мой взгляд, это успокоительная пилюля от Центробанка и для бизнеса, и для населения. Ее можно сравнить с лекарством-пустышкой: вреда нет, но и пользы тоже (МН. 14.02.2020);

Предлагаю в связи со всем этим клиническим и безобразным зудом срочно провести тотальную диспансеризацию всех без исключения сотрудников специальных служб - полицейских, прокуроров и даже сотрудников нового следственного комитета (РР. 01.03.2012);

пересадка ответственности (НГ. 21.11.2007);

- смысловая переоценка действия патогенов:

Похоже, банкиров поразил вирус жадности (МH. 14.05.2020);

А созданные сверху партии лишь паразитируют на настроениях, о которых я уже сказал (НезГ. 08.08.2020);

Идеальные паразиты: те, кто сосал кровь у государства, снова требуют от него помощи (НД. 18.04.2020);

Россия - это не пуповина, это глист, который высасывает из Украины все соки (Взгляд. 22.11.2013);

Против меня направлены все ядовитые ковидные стрелы (Z. 04.08.2020).

Последний пример представляет собой цитату из речи белорусского президента Александра Лукашенко, который в данном случае имеет в виду, что его враги пытаются использовать пандемию как средство политического давления на него.

Названия болезнетворных микроорганизмов, сопряженные с прецедентным подтекстом, могут также стать ресурсом для языковой игры:

Бацилла и Харибда.

Как в Москве сражаются с коронавирусом (НГ. 28.02.2020);

Как прогнулась Светлана Хоркина (НГ. 16.02.2004).

В первом примере замена одного прецедентного мифологического имени на основе фонетической адаптации (Сцилла) на ассоциативно связанную с воздействием на организм лексему бацилла позволяет создать яркий и эмоционально заряженный образ современной ситуации. Во втором примере оценка духовно-нравственной и гражданской позиции известной олимпийской чем- 
В.В. Жура, Ю.В. Рудова, Е.Г. Семенова. Вторичные соматические номинации в медиатекстах

пионки по спортивной гимнастике Светланы Хоркиной осуществляется на основе переосмысления значения лексемы, указывающей на ее физические способности.

Особое место в рассматриваемых медиатекстах занимает олицетворение, при котором неодушевленным объектам приписываются признаки и функции живого организма:

Хоронить профессии (Газета. 05.04.2020);

Выживает крупнейший. Почему в России умирает малый бизнес (ФП. 11.11.2019).

В случае использования устойчивых фразеологических сочетаний переосмыслению подвергаются следующие денотативные зоны (понятийные области):

- понятия анатомии человека, связанные с обозначением частей тела и органов человека:

Злоумышленник вываливает на голову испуганному человеку вполне конфиденциальную информацию (Новые Ведомости. 17.04.2019);

Его руки были по локоть в американской и иранской крови (ФП. 09.01.2020);

...а провластные политтехнологи рвут на себе волосы (ЕАН. 16.08.2019);

Ненавижу это признавать, но карты, которые есть «на руках» у коронавируса, объективно сильнее (МК. 11.05.2020);

прочистить им мозги должно государство (MH. 12.04.2019);

- понятийный аппарат физиологии человека, называющий проявления и функции живого организма:

Впрочем, передышка окажется временной (MH.13.09.2018);

Нечего кормить чужого дядю (МН. 26.07.2018);

откровенный плевок властей в лицо стариков (Газета. 11.02.2020);

И властям начхать на данный проблемный участок дороги (47News. 08.08.2016);

Прокуратура дышит в затылок (Коммерсант. 30.08.2018);

- медицинские понятия, ассоциированные с семантикой терапевтических вмешательств:

его пытаются привести в чувства (МК. 11.05.2020); план должен быть такой: дать глоток свежего воздуха экономике (Ведомости. 26.01.2015);

Укол совести (НГ. 14.02.2020);

прививка от жадности (НГ. 10.12.2007);

- патофизиологический понятийный аппарат, определяющий болезненные состояния тела человека:

мелкий и средний бизнес «загибается на глазах» (МК. 12.05.2020);

Ярославский бизнес задыхается в условиях коронавируса (R. 26.05.2020);

- понятия, обозначающие воздействие на физическую сущность человека или его реакцию на него:

Затянули пояса (Газета. 14.05.2020);

На какую сумму им будет выгодней ободрать клиента (МН. 16.01.2020);

Поднимают пенсионный возраст и налоги в качестве исключительного варианта «для поддержки штанов» (МН. 04.11.2019);

Выколачивают с бедняг все до последних штанов (МН. 04.09.2019);

Вынырнешь - значит, «гибкий подход», примененный федеральным центром, себя оправдал. За что ему, центру, честь и хвала. Утонешь - сам виноват (МК. 14.05.2020).

Наряду с рассмотренными выше случаями употребления соматизмов в переносном значении, когда соматическая лексика подвергается переосмыслению и получает приращения смысла, отвечающие конкретному контексту употребления, в проанализированных медиатекстах она используется в прямом значении, зафиксированном в словарях. Это происходит в публикациях, затрагивающих вопросы здоровья и благосостояния людей:

Главное-себя прокормить(Газета. 13.05.2020);

В Молдове размер прожиточного минимума показывает, какая минимальная сумма нужна человеку, чтобы не умереть от голода и болезней. То есть этот показатель включает лишь те потребности, пренебречь которыми нельзя в силу биологической необходимости. Без них в организме запускаются дегенеративные процессы - ослабление, голод, болезни и, как итог, смерть (NM. 16.10.2019);

Великобритания может столкнуться с внутренним кризисом из-за пандемии COVID-19 (Газета. 14.05.2020). 


\section{МАТЕРИАЛЫ И СООБЩЕНИЯ}

Приведенные контексты свидетельствуют о том, что применение соматической лексики позволяет создать второй план, или подтекст, сопровождающий передачу фактуальной информации. Он имеет субъективный характер и передает авторскую оценку сообщаемого. Последняя, как правило, эмотивна, что обусловлено существованием устойчивых коннотаций, закрепленных за лексемами, выражающими базовые понятия физического существования человека. Так, смерть, боль, страдание, различные виды заболеваний и патологических изменений организма упоминаются при характеристике негативной ситуации:

Смерть демократии в Нигерии(НВ. 06.03.2019);

Страдает при этом и политика, и история (Beдомости. 29.09.2016);

Головная боль крымских депутатов и чиновников (ЭМ. 07.11.2014);

Министр культуры РФ: польских политиков поразила историческая амнезия (КВ. 04.08.2017).

Выздоровление, улучшение здоровья имеют положительный аксиологический потенциал:

Российской экономике предрекли быстрое выздоровление после пандемии (L. 06.08.2020);

Китайская экономика пошла на поправку, нопопрежнему остается в минусе (Эксперт. 30.03.2020).

Образное содержание вторичной номинации, создаваемое в результате взаимодействия прямого и переносного значений в ходе употребления соматизмов в нетривиальных контекстах, также способствует эмоциональному восприятию описываемой ситуации:

Рынок труда в Приморья бьется в конвульсиях(К. 04.07.2019).

Оценочность, появляясь в качестве ассоциативного компонента прямого значения соматических лексем, впоследствии может фиксироваться в словарной дефиниции их переносного значения и усиливаться за счет контекстуального наведения эмотивных сем в тексте. Рассмотрим пример:

Бацилла радикализма всегда в обществе присутствует, как вирусы в организме человека. Но если иммунитет достаточен, болезнь не развивается (Ведомости. 16.12.2010).

В контексте использована лексема баџил$л а$, у которой в настоящее время зафиксировано два значения: 1. Болезнетворная бактерия в форме палочки. 2. перен. О каком-н. отрицательном, вредоносном свойстве, распространяющемся подобно заразе (СИС) (выделено нами. $B$. Ж.). В содержание первого лексико-семантического варианта включено указание на характер этой бактерии - болезнетворная, что реализует ее негативный аксиологический потенциал. В переносное значение входят оценочные атрибутивы - отрицательное, вредоносное, прямо указывающие на характер оценки данного явления. Под влиянием данной лексемы происходит переосмысление слова радикализм, обозначающего решительный образ действий, за счет добавления негативной эмотивно-оценочной семы. Кроме того, развернутая метафора, создающая образ общества как живого организма, подвергающегося атакам чужеродных патогенов и включающего механизм зашиты против них, усиливает оценочный аспект, одновременно выражая эмоциональные смыслы тревоги и переживания за происходящее.

В следующем примере эмотивно-оценочный потенциал высказывания возникает в результате употребления развернутой метафоры, сопряженной со стилистической градацией:

Конечно, надо отдавать себе отчет в том, что в борьбе за здоровье падут целые полицейские службы. Мы, очевидно, потеряем и УБЭП, и ГИБДД, как полностью пораженные и иммуноинфицированные. Обидно, но не смертельно. По аналогии с гангреной их придется ампутировать (РР. 01.03.2012).

Автор призывает к борьбе с коррупцией в органах власти (борьба за здоровье), которая должна привести к радикальной мере-ux амnутащчи . Эмоциональная образность данного высказывания направлена на эвокацию таких чувств, как глубокое осуждение и презрение. Кроме того, экспрессивность содержания способствует адекватному восприятию авторской расстановки смысловых акцентов в тексте.

Полученные нами данные подтверждают выводы других исследователей о преимущественно эмотивном характере морбиальной 
метафоры [Чудинов, 2001, с. 69; Ляпун, 2008, c. 143], который акцентирует и усиливает, главным образом, негативную оценочность этого стилистического явления в экономических и политических текстах современной эпохи. В политических текстах соматические вторичные номинации выступают мощным средством создания иронии. Так, в заголовке политической статьи Гнойники в здравоохранении (Зебра. 31.10.2013) иронический эффект возникает в результате сочетания двух разнополюсных понятий по типу оксюморона. Отрасль государственной деятельности, целью которой является сохранение здоровья социума, сама становится носителем заболевания.

Рассмотрение эмотивно-оценочного потенциала высказываний с вторичными соматическими номинациями позволило выявить такие важные функции этих номинаций, как изобразительная и прагматическая.

\section{Заключение}

В последние два десятилетия в медиатекстах экономической, деловой и политической направленности для концептуализации действительности активно используются соматические лексемы, что обусловлено медикализацией современного общества и общей гносеологической направленностью категоризации внешнего мира через призму телесности.

В результате изучения функционирования вторичных номинаций на основе соматизмов установлены и детализированы источники соматической экспансии, лежащие в основе переосмысления, то есть семантические области, к которым рассматриваемые вторичные номинации относятся в первичном значении. Смысловой трансформации подвергаются собственно соматизмы, представляющие такие сферы, как названия различных частей человеческого тела и патологии организма, и условные соматизмы, то есть номинации, включающие в свое значение понятийные признаки, указывающие на изменение состояния /статуса тела человека, соматические проявления и функции, манипуляции или воздействие на организм человека.

Выявлены новые денотативные зоны / понятийные области, для означивания которых применяются вторичные соматические номинации в изучаемых медиатекстах. В публи- кациях экономической и деловой направленности это: субъект и объект деятельности, их действия и поведение, состояние экономической деятельности / деловой активности, в публикациях политической направленности субъект политической деятельности, его духовно-нравственная позиция, политическая ситуация и события. Последовательность изменений в семантике вторичных семантических номинаций состоит из следующих этапов: первоначально соматическая номинация имеет конкретно-референтное значение, используясь в профессиональных медицинских и научных контекстах. При перемещении ее в другие дискурсы присущее ей значение приобретает диффузный характер, возникает нечеткость его семантических границ. Впоследствии появляется новое, абстрактно-референтное значение, «наведенное» контекстом.

Вторичные номинации в изучаемых текстах создаются посредством разнообразных приемов: сравнения, метафоры, метонимии, использования устойчивых фразеологических сочетаний, эпитетов, а также иронии, оксюморона, градации и языковой игры.

Выявлено, что эмотивная оценочность, сопровождающая вторичные соматические номинации, является результатом существования устойчивых эмоциональных и оценочных коннотаций, закрепленных за данными лексемами в их первичном значении. Последние обусловлены тем фактом, что такие лексические единицы обозначают явления, процессы, ставящие под угрозу либо оптимизирующие физическое существование человека. Установлено, что использование вторичных соматических номинаций в медиатексте создает, как правило, эмоционально окрашенное, нагляднообразное представление того или иного объекта, требующее от реципиента выхода за рамки узуального значения для декодирования / расшифровки перлокутивного эффекта сообщения, что способствует достижению прагматической цели высказывания.

Вторичные номинации выполняют в текстах экономической, деловой и политической направленности функцию номинирования, представляя внешний и внутренний мир человека в терминах соматических понятий, а также инструментальную, моделирующую и эвфемистическую функции. 


\section{МАТЕРИАЛЫ И СООБЩЕНИЯ}

Изучение особенностей вторичного переосмысления соматизмов в экономических, деловых и политических медиатекстах позволило раскрыть концептуальный и ценностный аспекты языковой картины современного российского общества и установить направления и способы текстовой репрезентации реальности в указанных сферах.

\section{ПРИМЕЧАНИЕ}

${ }^{1}$ Контексты, извлеченные из данных источников, использованы исключительно в качестве материала исследования. Мнение авторов статьи может не совпадать с мнением авторов публикаций, размещенных в сети Интернет.

\section{СПИСОК ЛИТЕРАТУРЫ}

Бурганова Л. А., Савельева Ж. В., 2009. Медикализация и эстетизация здоровья в рекламной коммуникации // Социологические исследования. № 8. С. 100-107.

Голодов А.Г., 2010. Вторичная номинация в отраслевой лексике // Вестник Рязанского государственного университета имени С.А. Есенина. № 2 (27). С. 77-87.

Голубых А. А., 2019. «Медикализация» современной англоязычной интернет рекламы (на материале рекламных видеороликов видеохостинга Youtube) // Вестник Самарского университета. История, педагогика, филология. Т. 2, №4. С. 162-169.

Дмитриева Е. В., 2003. Еще раз о понятиях. От социологии медицины к социологии здоровья // Социологические исследования. № 11. URL: http://www.isras.ru/files/File/Socis/2003-11/ dmitrieva.pdf. (дата обращения: 18.08.2020).

Жура В. В., Рудова Ю. В., 2014. Корпореальная культура как отражение процесса медикализации общества и ее репрезентация в медицинском дискурсе // Гуманитарные и социальные науки. № 2. С. 551-554.

Лаврищева Е. В., 2018. Роль физиологической метафоры в репрезентации когнитивного фрагмента «эмоциональное пространство» // Научный результат. Вопросы теоретической и прикладной лингвистики. T. 4, № 1. С. 13-21.

Ляпун С. В., 2008. Метафорическая оценочность в аналитическом газетном тексте // Вестник Тамбовского университета. Серия: Гуманитарные науки. № 7 (63). С. 141-147.
Масалева Н. В., 2009а. Семантические трансформации в соматической лексике (на материале русского, чешского и сербского языков) // Языковые категории и единицы: синтагматический аспект : материалы Восьмой Междунар. конф. Владимир : ВГГУ. С. 209-212.

Масалева Н. В., 2009б. Феномен «телесной» красоты в русской и сербской фразеологии // Личность. Культура. Общество. Т. 11, № 2 (48-49). C. 389-393.

МугуР. Ю., 2003. Полисемантизм соматической лексики (на материале русского и немецкого языков) : автореф. дис. ... канд. филол. наук. Майкоп. 24 с.

Новрузова Г. Г., 2009. Соматическая лексика антропоцентрической направленности русского и английского языков // Lingua mobilis. № 5 (19). C. $168-176$.

Покровская Е. В., 2006. Прагматика современного газетного текста // Русская речь. № 3. С. 81-87.

Рудова Ю. В., Жура В. В., 2017. Метафорические номинации в характеристике понятий корпореальной культуры // Известия высших учебных заведений. Поволжский регион. Гуманитарные науки. № 2 (42). С. 94-106.

Чудинов А. П., 2001. Россия в метафорическом зеркале : Когнитивное исследование политической метафоры (1991-2000). Екатеринбург : Урал. гос. пед. ун-т. 238 с.

Zhura V. V., Rudova Yu. V., Martinson Zh. S., 2017. Narrative Continuum of Corporeal Culture. Proceedings of the $7^{\text {th }}$ International Scientific and Practical Conference "Current Issues of Linguistics and Didactics: The Interdisciplinary Approach in Humanities" (CILDIAH 2017). Paris : Atlantis Press. Vol. 97. P. 342-347. DOI: https://doi.org/10.2991/cildiah-17.2017.60.

\section{ИСТОЧНИКИ}

Ведомости - Ведомости. URL: https://www. vedomosti.ru.

Взгляд - Взгляд. Деловая газета. URL: https://vz.ru.

Газета - Газета. URL: https://gazeta.ru.

$E A H$ - ЕАН. Интерактивные новости. URL: https:// eanews.ru.

Зебра-Зебра. URL: https://zebra-tv.ru.

ИА - ИА «НТА Приволжье». URL: https://nta-nn.ru.

Известия - Известия. URL: https://iz.ru.

$K B$ - Красная весна. URL: https://rossaprimavera.ru. Коммерсант - Коммерсантъ. URL: https:// kommersant.ru.

КП-Комсомольская правда. URL: https://kp.kz/daily.

MK-MK. URL: https://mk.ru.

MH-Мир новостей. URL: https://mirnov.ru.

$H B$ - HB. URL: https://nv.ua. 
Hовые ведомости - Новые ведомости. URL: https://nvdaily.ru.

НГ- Новая газета. URL: https://novayagazeta.ru. НД-Новости дня. URL: https://19rus.info/index.php. НезГ-Независимая газета. URL: https://ng.ru. OГ-«Открытая» газета. URL: https://opengaz.ru.

$\Pi B$ - Пугачевское время. URL: https:// pugachevskoevremya.ru.

ПЭ-Политэксперт. URL: https://politexpert.net. $P$ - Рамблер. URL: https://news.rambler.ru.

РБК-PБK. URL: https://rbc.ru.

СБЕР Про - СБЕР Про. URL: https://sber.pro.

CИС - Словарь иностранных слов. URL: https:// classes.ru.

ФП-ФедералПресс. URL: https://fedpress.ru. Эксперт - Эксперт. URL: https://expert.ru. ЭM-Эхо Москвы. URL: https://echo.msk.ru. $K$-Konkurent.Ru. URL: https://konkurent.ru. L-LENTA.RU. URL: https://lenta.ru.

47News-47News. RL: https://47news.ru.

$N M$-NewsMaker. URL: https://newsmaker.md. $P P$ - PEN \& PAPER. URL: https://pen-paper.ru. $R$-ИA Regnum. URL: https://regnum.ru. Z-Znak. URL: https://www.znak.com.

\section{REFERENCES}

Burganova L.A., Saveleva Zh.V., 2009. Medikalizatsiya i estetizatsiya zdorovya v reklamnoy kommunikatsii [Medicalization and Optimization of Health in Advertising]. Sotsiologicheskie issledovaniya [Sociological Studies], no. 8, pp. 100-107.

Golodov A.G., 2010. Vtorichnaja nominacija v otraslevoj leksike [Secondary Nomination in Professional Jargon]. Vestnik Ryazanskogo gosudarstvennogo universiteta imeni S.A. Esenina [Bulletin of Ryazan State Universitynamed for S.A. Yesenin], no. 2(27), pp. 77-87.

Golubykh A.A., 2019. «Medikalizatsiya» sovremennoy angloyazychnoy internet-reklamy (na materiale reklamnykh videorolikov videohostinga youtube) ["Medicalization" of Modern Internet Advertising (Based on English Youtube Commercials)]. Vestnik Samarskogo universiteta. Istoriya, pedagogika, filologiya [Vestnik of Samara University. History, Pedagogics, Philology], vol. 2, no. 4, pp. 162-169.

Dmitrieva E.V., 2003. Eshheraz oponyatiyakh. Otsotsiologii mediciny k sotsiologii zdorovya [On Definitions Once Again. From Sociology of Medicine to Sociology of Health]. Sotsiologicheskie issledovaniya [Sociological Studies]. URL: http:// www.isras.ru/files/File/Socis/2003-11/dmitrieva.pdf (accessed 18 August 2020).

Zhura V.V., Rudova Yu.V., 2014. Korporealnaya kultura kak otrazhenie protsessa medikalizaii obshchestva $\mathrm{i}$ ee reprezentatsiya $\mathrm{v}$ meditsinskom diskurse
[Corporeal Culture As a Reflection of the Process of Medicalization of Society and Its Representation in Medical Discourse]. Gumanitarnye i sotsialnye nauki, no. 2, pp. 551-554.

Lavrishheva E.V., 2018. Rol fiziologicheskoy metafory v reprezentatsii kognitivnogo fragmenta «emotsionalnoe prostranstvo» [The Role of a Physiological Metaphor in the Representation of the Cognitive Fragment "Emotional Space"]. Nauchnyy rezultat. Voprosy teoreticheskoyi prikladnoy lingvistiki [Research Result. Theoretical and Applied Linguistics], vol. 4, no. 1, pp. 13-21.

Lyapun S.V., 2008. Metaforicheskaya otsenochnost v analiticheskom gazetnom tekste [Metaphorical Evaluation in an Analytical Newspaper Text]. Vestnik Tambovskogo universiteta. Serija: Gumatirnye nauki [Tambov University Review. Series Humanities], no. 7 (63), pp. 141-147.

Masaleva N.V., 2009a. Semanticheskie transformatsii v somaticheskoy leksike (na materiale russkogo, cheshskogo i serbskogo yazykov [Semantic Transformations in Somatic Lexis (As Exemplified by Russian, Czech and Serbian languages]. Yazykovye kategorii i edinitsy: sintagmatichesky aspect: materialy Vosmoy Mezhdunar. konf. [Language Categories and Units: The Syntagmatic Approach. Proceedings of the $8^{\text {th }}$ International Conference]. Vladimir, VGGU, pp. 209-212.

Masaleva N.V., 2009b. Fenomen «telesnoy» krasoty v russkoy i serbskoy frazeologii [The Phenomenon of "Body" Beauty in Russian and Serbian Phraseology]. Lichnost. Kultura. Obshchestvo [Person. Culture. Society], vol. 11, no. 2(48-49), pp. 389-393.

Mugu R. Yu., 2003. Polisemantizm somaticheskoн leksiki (na materiale russkogo i nemetskogo yazykov): avtoref. dis. ... kand. filol. nauk [Polysemantism of Somatic Lexis (Based on Materials of the Russian and German Languages). Cand. philol. sci. abs. diss.]. Maykop. 24 p.

Novruzova G.G., 2009. Somaticheskaya leksika antropotsentricheskoy napravlennosti russkogo i angliyskogo yazykov [Somatic Human-Centred Lexis in the English and Russian Languages]. Lingua mobilis, no. 5 (19), pp. 168-176.

Pokrovskaya E.V., 2006. Pragmatika sovremennogo gazetnogo teksta [Pragmatics of Modern Newspaper Text]. Russkaya rech [Russian Speech], no. 3, pp. 81-87.

Rudova Yu.V., Zhura V.V., 2017. Metaforicheskie nominatsii $\mathrm{v}$ kharakteristike ponyatiy korporealnoy kultury [Metaphors As the Main Concepts of Corporeality]. Izvestija vysshih uchebnyh zavedenij. Povolzhskij region. Gumanitarnye nauki [University Proceedings. Volga Region. Humanities], no. 2 (42), pp. 94-106. 
Chudinov A.P., 2001. Rossiya v metaforicheskom zerkale: kognitivnoe issledovanie politicheskoy metafory (1991-2000) [Russia in the Metaphorical Mirror: A Cognitive Study of Political Metaphors]. Yekaterinburg, Uralsky gosudarstvenny pedagogichesky universitet. $238 \mathrm{p}$.

Zhura V.V., Rudova Yu.V., Martinson Zh.S., 2017. Narrative Continuum of Corporeal Culture. Proceedings of the $7^{\text {th }}$ International Scientific and Practical Conference "Current Issues of Linguistics and Didactics: The Interdisciplinary Approach in Humanities" (CILDIAH 2017). Paris, Atlantis Press. Vol. 97, pp. 342-347. DOI: https://doi.org/ 10.2991/cildiah-17.2017.60.

\section{SOURCES}

Vedomosti. URL: https: // www.vedomosti.ru. Vzgljad. Delovaja gazeta. URL: https://vz.ru. Gazeta. URL: https://gazeta.ru.

EAN. Interaktivnye novosti. URL: https://eanews.ru. Zebra. URL: https://zebra-tv.ru.

IA «NTA Privolzh'e». URL: https://nta-nn.ru.

Izvestija. URL: https://iz.ru.

Krasnaja vesna. URL: https://rossaprimavera.ru.
Kommersant. URL: https://kommersant.ru. Komsomol'skaja pravda. URL: https://kp.kz/daily. MK. URL: https://mk.ru.

Mir novostej. URL: https://mirnov.ru.

$N V$. URL: https://nv.ua.

Novye vedomosti. URL: https://nvdaily.ru.

Novaja gazeta. URL: https://novayagazeta.ru.

Novosti dnja. URL: https://19rus.info/index.php.

Nezavisimaja gazeta. URL: https://ng.ru.

«Otkrytaja» gazeta. URL: https://opengaz.ru.

Pugachevskoe vremja. URL: https:// pugachevskoevremya.ru.

Politjekspert. URL: https://politexpert.net.

Rambler. URL: https://news.rambler.ru.

$R B K$. URL: https://rbc.ru.

SBER Pro. URL: https://sber.pro.

Slovar' inostrannyh slov. URL: https://classes.ru.

FederalPress. URL: https://fedpress.ru.

Jekspert. URL: https://expert.ru.

Jeho Moskvy. URL: https://echo.msk.ru.

Konkurent.Ru. URL: https://konkurent.ru.

LENTA.RU. URL: https://lenta.ru.

47News. RL: https://47news.ru.

NewsMaker. URL: https://newsmaker.md.

PEN \& PAPER. URL: https://pen-paper.ru.

IA Regnum. URL: https://regnum.ru.

Znak. URL: https://www.znak.com.

\section{Information About the Authors}

Viktoriya V. Zhura, Doctor of Sciences (Philology), Associate Professor, Head of the Department of Foreign Languages with a Course of Latin, Volgograd State Medical University, Pavshikh Bortsov Sq., 1, 400131 Volgograd, Russia, vvzhura@gmail.com, https://orcid.org/0000-0002-8128-701X

Yuliya V. Rudova, Candidate of Sciences (Philology), Associate Professor, Department of Foreign Languages with a Course of Latin, Volgograd State Medical University, Pavshikh Bortsov Sq., 1, 400131 Volgograd, Russia,juliarud@inbox.ru, https://orcid.org/0000-0001-7722-6831

Yelena G. Semenova, Senior Lecturer, Department of Foreign Languages with a Course of Latin, Volgograd State Medical University, Pavshikh Bortsov Sq., 1, 400131 Volgograd, Russia, yaitskova@mail.ru, https://orcid.org/0000-0002-9027-494X

\section{Информация об авторах}

Виктория Валентиновна Жура, доктор филологических наук, доцент, заведующая кафедрой иностранных языков с курсом латинского языка, Волгоградский государственный медицинский университет, пл. Павших Борцов, 1, 400131 г. Волгоград, Россия, vvzhura@gmail.com, https://orcid.org/0000-0002-8128-701X

Юлия Владимировна Рудова, кандидат филологических наук, доцент кафедры иностранных языков с курсом латинского языка, Волгоградский государственный медицинский университет, пл. Павших Борцов, 1, 400131 г. Волгоград, Россия, juliarud@inbox.ru, https://orcid.org/0000-0001-7722-6831

Елена Геннадиевна Семенова, старший преподаватель кафедры иностранных языков с курсом латинского языка, Волгоградский государственный медицинский университет, пл. Павших Борцов, 1, 400131 г. Волгоград, Россия, yaitskova@mail.ru, https://orcid.org/0000-0002-9027-494X 